UDC: 37.011 .31

\author{
Yaroslav Galeta, \\ PhD (Candidate of Pedagogical Sciences), associate professor, \\ Department of Pedagogy and Education Management, \\ The Kirovohrad Volodymyr Vynnychenko State Pedagogical University, \\ 1, Shevchenka Str., Kropyvnytskyi, Ukraine
}

\title{
ISSUES OF TRAINING MATHEMATICS TEACHERS PRESENTED IN PSYCHOPEDAGOGICAL RESEARCH WORKS
}

The author has considered research works and publications on the problems of professional training of Mathematics teachers and approaches to solving them. The formation of Mathematics teacher's methodical and information culture has been covered. A number of contradictions characterising the level of subject-related and pedagogical training of future Mathematics teachers have been considered.

Keywords: problems of training future Mathematics teachers, subject-related and pedagogical training of Mathematics teachers, professional orientation.

Introduction. New conditions of social development require changes in implementation of the opportunities for professional activities, level up requirements for the quality of education and its informatisation, professional training and management.

Professional training is a systemic and multifaceted phenomenon with a certain content and structure. The content of the system of professional training as a branch of education consists of a chain of professional education institutions, and the structure consists of integrated regulatory documents regulating arrangement of their work and reciprocal relationships. For this reason, it is necessary to provide effective training and professional advancement of academic staff [2].

Review of experience in Mathematics teachers' training has shown that not all resources have been deployed for coping with this task. It is necessary to update aims, content, organisational forms, and methods of teaching while training future teachers of Mathematics. In terms of pedagogical higher education, it is essential to develop working models and technologies of arranging training and educational process based on contemporary theoretical and methodological background, select appropriate content, keep traditional and test innovative forms and methods of professional training.

Prominent scientists (V. Bondar, A. Boiko, V. Butenko, I. Ziaziun, V. Hrynova, O. Moroz, O. Piekhota, O. Savchenko) consider pedagogical education modernisation as a factor of gradual optimisation of professional training of a new teacher in the new age. The research works by the above-mentioned scientists cover various approaches to the understanding of teacher training. The problem of pedagogical education modernisation is rather acute; however, the specific problem of training Mathematics teachers under new conditions has not become specific research subject in Ukrainian pedagogy.

The paper is aimed at brief analysis of recent research works and publications covering the issue of pro- fessional training of Mathematics teachers and distinguishing approaches to coping with this issue.

Discussion. Mathematical education holds a prominent place and is of great importance in the system of general education. Its role is determined by the impact of mastering mathematical knowledge and work methods on development of general culture of a modern human. Considering new objectives in teaching mathematics at education and vocational schools within the new educational paradigm and regarding intrinsic problems of acquiring knowledge of mathematics, training future Mathematics teachers should be considered as a separate issue both practically and theoretically.

In O. Chemerys opinion, training future teachers of Mathematics is directly associated with providing performance quality of teacher training at higher educational institutions; it has gained significance in a great number of developed countries in the last third of the $20^{\text {th }}$ century for several reasons: the beginning of transition from industrial society to knowledge society whose economics is based on natural-science and high technology achievements, and specialists with higher education are required at the labour market; the transition to educational mainstream at first and to general higher education afterwards (involving more than $60 \%$ of youth) and the need for educating a large number of people with low level of capabilities for mastering classical academic programmes at the established level; saturation of labour market with graduates of higher educational institutions and rivalry between them for workplaces; elimination of borders and other barriers for students, teachers and researchers' mobility, creating open labour market for graduates [3].

In his thesis research, S. Rybak has defined methodological, didactic and constructive challenges of training teachers of physics/mathematics: intensive development of integration processes in science, technology, society, and level of their representation in the content of mathematical and specialist disciplines for training teachers; the relevance of involving natural and mathematical discip- 
lines into the integral system of education and traditional orientation of subjects at abstract knowledge teaching of students that until now has been separated from the holistic noospheric structure where human worldview is being formed; the need for substantive thinking development (physical, mathematical, technical), the formation of students' ideas about the unity of the world, etc. [3].

The formation of Mathematics teacher's methodical culture was investigated in the Doctor's thesis by I. Novyk, who proposed the conception of continuous methodical preparation of Mathematics teachers and studied the issue of exercising interdisciplinary relationships in the process of methodical preparation of future Mathematics teachers [4]. Didactic and methodical basics of interrelations and consistency of structures of mathematical education at higher teacher training educational institutions and comprehensive and vocational schools were developed by T. Talahanov, I. Prodanov and Ye. Smirnov.

For example, V. Hilev has proposed a technique of forming future Mathematics teachers' abilities to carry out methodical analysis of teaching material, developed a complex of exercises intended for the formation of the above-mentioned abilities. A Raukhman studied the process of forming future Mathematics teachers' methodical abilities and skills associated with mathematical abstraction. In the works by M. Zhaldak and his students, much attention was paid to the formation of Mathematics teachers' information culture, application of new teaching information technology while teaching Mathematics to both secondary school students and future teachers.

The outstanding German mathematician Felix Klein substantiated the relevance of professionally oriented training of future Mathematics teachers in his work entitled "Elementary Mathematics from an Advanced Standpoint" and wrote, "Having been accepted into a higher school, a young student has to deal with the tasks that are completely different from the ones he/she used to deal with; naturally, the student forgets what he/she studied before. After university, when the student becomes a teacher, he/she is supposed to teach traditional mathematics and often cannot associate this new mission with the knowledge obtained at the university; so, he/she masters the old tradition rather quickly and university education can only bring back pleasant (or unpleasant) memories that have no impact on his/her teaching Maths" [4].

A similar situation occurred (and, unfortunately, occurs) in Ukrainian pedagogical universities. This problem has been partially solved due to numerous works devoted to professional orientation or the so-called "pedagogisation" of teaching specialist mathematical disciplines to future teachers of Mathematics.

It appears that the term "pedagogisation" was introduced in Ukraine in 1955 for the first time by I. Shymanskyi, who wrote that pedagogisation of Mathematical Analysis course involves its association with the specialisation of a future specialist, which should be implemented as follows [5]:
- all the issues of the programme that are of direct relevance to teaching Mathematics at school must be taught in such a way that a student (a future teacher) could use this material (at least some parts of it) in his/her work as a teacher;

- it is necessary to present theoretical issues of Mathematical Analysis course related to the introduction of polytechnical education to students;

- finally, it is necessary to get students acquainted with the material that they will probably use at the classes of school mathematical interest group.

In 1957, N. Vilenkin and I. Yahlom also highlighted the necessity for finding connections with mathematics learned at school in addition to teaching all specialist mathematical disciplines and proposed some ways of improving curriculums and study programmes intended for teaching Mathematics at teacher training universities [1].

As noted by Ye. Smirnov, one of the central problems of mathematical education for future teachers is current double gap between mathematics taught at school and university, when there is the necessity for teaching elementary mathematics from the advanced standpoint [3]. The scientist distinguished a number of contradictions characterising the levels of subject-specific and pedagogical training of Mathematics teachers:

- between the content of learning and teaching support of education and the objective need for a comprehensive didactic system of teaching a discipline at a pedagogical institution;

- between the level of development of theoretical principles of psychology and pedagogy, practical significance of the content of the subject (basic concepts, procedures, methods, evidence, actions) and commonality, narrow focus of methods intended for teaching the subject at the university;

- between orientation at making up the content of subject-specific education on the basis of specifics and necessity to take into account psychological characteristics of sensory-perceptive processes of adequate perception of mathematical information by students [3].

H. Perevalov considered professional orientation in teaching mathematical analysis to future Mathematics teachers as a profound consideration of all the connections of the subject learned with school mathematics, indepth study of all the concepts, ideas and facts relating to school mathematics.

An integral conception of professional orientation of training Mathematics teachers was developed by O. Mordkovych. It is based on the principles that were partially complemented by $\mathrm{H}$. Mykhalin and were taken as a basis for creating a methodical system of teaching mathematical analysis to future Mathematics teachers [3]:

- the principle of differential fundamentality (fundamental mathematical training should be not only the aim, but also a means of training teachers of Mathematics);

- the principle of "generalisation for simplification", according to which, the transition to more general objects often makes the theory more clear and easy to understand 
compared to studying this theory on the basis of less general objects;

- the principle of minimising the time for studying the course under conditions of rather slow increase of abstraction of the material, beginning from the level of abstraction of school mathematics;

- integratedness principle (studying a large number of factors at the same time for the so-called real and complex cases; paying attention to the unity of mathematical, methodical, pedagogical, psychological, informational, linguistic, and moral branches);

- the principle of the key idea (strong correlation between the course of mathematical analysis and school mathematics and their mutual influence);

- the principle of "teaching to teach in the process of teaching";

- continuity principle (professional culture of Mathematics teacher is being formed throughout life).

H. Mykhalin understood professional orientation of teacher's training as such kind of teaching that provides formation of greatest possible number of components of teachers' professional culture [3].

Most of the works associated with professional orientation of training future Mathematics teachers are devoted to the formation of their mathematical or methodological culture.

For example, this problem was investigated in the papers by N. Vilenkin and O. Mordkovych, where they shared their experience in teaching such units of mathematical analysis as "Introduction to Analysis", "Differential Calculus", "Integral Calculus" to future teachers of Mathematics. The authors emphasise the necessity for applying various approaches to introducing basic elementary functions when teaching future Mathematics teachers [1].

O. Mordkovych suggested that one of the most important functions of mathematical problems in the process of teaching is the methodical one which is associated with the formation of future Mathematics teacher's ability to teach solving problems. In the author's opinion, studying special mathematical disciplines should provide not only high level of mathematical culture of Mathematics teachers, but to facilitate the formation of their methodical

\section{ЛІТЕРАТУРА}

1. Виленкин Н. Я. Подготовку учителей математики - на уровень современных требований (предложения, мнения, поиск) / Н. Я. Виленкин, А. Г. Мордкович // Математика в школе. - 1986. - № 6. - С. 6-10.

2. Енциклопедія освіти / АПН України; головний ред. В. Г. Кремень. - К. : Інком Інтер, 2008. - 1040 с.

3. Михалін Г. О. Усунення деяких логічних прогалин шкільного курсу математики засобами математичного аналізу / Г. О. Михалін, О. П. Томащук . - К. : УдПУ, 1995. - 96 с. culture for them to be able to teach with the appropriate level of severity and abstractedness [1].

The issue of forming Mathematics teacher's professional culture in the process of his/her studies was investigated in the Candidate's thesis of O. Tomashchuk, where he distinguished and partially solved a number of problems associated with implementation of the principle of professional orientation of teaching mathematical analysis to future Mathematics teachers [4]:

- the problem of creating qualification description of modern Mathematics teacher;

- the problem of identification and specification of result-oriented aims of teaching mathematical disciplines, including mathematical analysis;

- the problem of identifying the content, methods, means, and forms of teaching mathematical analysis, which would provide the achieving of the definite resultoriented aims.

Therefore, it is possible to distinguish the following approaches to solving the problems of professional training of future Mathematics teachers: specialist training conception based on the formation of professional culture (O. Tomashchuk), the conception of professional (pedagogical) orientation of students' training in Mathematics (O. Mordkovych), the system of continuous methodical preparation oriented at the formation of mathematical culture in Mathematics teachers (N. Vilenkin).

Conclusions. Despite a large number of works investigating the issue of training future teachers of Mathematics, the formation of professional culture, mathematical culture in the process of studying at the university, this issues requires further studies, as long as high-technology civilisation that has entered informational and computerised $21^{\text {st }}$ century requires reconciling inconsistency between its needs and content, methods, forms, and means of teaching and education.

For example, the issue of defining the concept "mathematical culture of future Mathematics teachers" required further study together with related problems of defining the content, methods, means, and organisational forms of teaching that would provide the formation of basics of mathematical culture in future Mathematics teachers.

4. Новик И. А. Формирование методической культуры учителя математики в педвузе / И. А. Новик. - Минск : БГПУ, 2003. - 178 с.

5. Шиманський I. Є. До питання педагогізації викладання математичних дисциплін в педагогічних інститутах / I. С. Шиманський // Наукові записки Київського педінституту, 1955. - T. XVII. - Пед. серія № $1 .-$ C. $121-127$. 


\section{REFERENCES}

1. Vilenkin, N. Ya., Mordkovich, A. G. (1986) Podgotovku uchiteley matematiki - na uroven sovremennykh trebovaniy (predlozheniya, mneniya, poisk) [Training Mathematics teachers should meet contemporary requirements (suggestions, opinions, search)]. Matematika v shkole - Mathematics at school, 6, 6-10 [in Russian].

2. Kremen, H. (Ed.). (2008). Entsyklopediia osvity [Education encyclopedia]. Kyiv: Inkom Inter [in Ukrainian].

3. Mykhalin, H. O., \& Tomashchuk, O. P. (1995). Usunennia deiakykh lohichnykh prohalyn shkilnoho kursu matematyky zasobamy matematychnoho analizu [Eliminating some logical gaps in school course of mathematics by means of mathematical analysis]. Kyiv: UDPU [in Ukrainian].

4. Novik, I. A. (2003). Formirovanie metodicheskoy kultury uchitelya matematiki $v$ pedvuze [The formation of methodical culture of Mathematics teachers at pedagogical universities]. Minsk: BGPU [in Ukrainian].

5. Shymanskyi, I. Ye. (1955). Do pytannia pedahohizatsii vykladannia matematychnykh dystsyplin $\mathrm{v}$ pedahohichnykh instytutakh [On the issue of pedagogisation of teaching mathematical subjects at pedagogical universities]. Naukovi zapysky Kyivskoho pedinstytutu Proceedings of Kyiv pedagogical Univeristy, 1, 121-127. (Vols. 17) [in Ukrainian].

\section{Ярослав Володимирович Галета, дочент кафедри педагогіки та освітнього менеджменту, Кіровоградський державний педагогічний університет імені В. Винниченка, вул. Шевченко, 1, м. Кропивницький, Украӥна}

\section{ПРОБЛЕМИ ПРОФЕСІЙНОЇ ПІДГОТОВКИ ВЧИТЕЛЯ МАТЕМАТИКИ У ПСИХОЛОГО-ПЕДАГОГІЧНИХ ДОСЛІДЖЕННЯХ}

У статті розглянуті дослідження та публікації з проблеми професійної підготовки майбутніх учителів математики та підходи до розв'язання відповідних завдань. Зазначено, що професійна підготовка є системним, багатоплановим та багатогранним явищем, що має певний зміст і структуру. На основі наукового дослідження С. М. Рибак визначено суперечності методологічного, дидактичного і конструктивного характеру у підготовці учителів фізикоматематичного циклу. Висвітлено проблему формування методичної та інформаційної культури вчителя математики на засадах концепції неперервної методичної підготовки вчителя математики та здійснення міжпредметних зв'язків у процесі методичної підготовки майбутніх учителів математики. Розглянуто ряд суперечностей, що характеризують рівень предметної та педагогічної підготовки вчителя математики, а саме: між змістом навчально-методичного забезпечення освіти та об'єктивною необхідністю наявності цілісної дидактичної системи викладання дисципліни в педагогічному закладі; між рівнем розвитку теоретичних положень психології та педагогіки, практичною значущістю предметного змісту та уніфікованістю, вузькою спрямованістю методики викладання навчальної дисципліни у виші; між орієнтацією на побудову змісту предметної освіти на основі ії специфіки та необхідністю врахування психологічних характеристик сенсорно-перцептивних процесів адекватного сприйняття математичного змісту студентами. В результаті аналізу наукової літератури виділено підходи до розв'язання завдань професійної підготовки майбутнього вчителя математики: концепція підготовки фахівця, яка грунтується на формуванні професійної культури (О. П. Томащук), концепція професійно-педагогічної спрямованості математичної підготовки студентів (О. Г. Мордкович), система неперервної методичної підготовки, зорієнтованої на формування математичної культури вчителя математики (Н. Я. Віленкін).

Ключові слова: проблеми професійної підготовки майбутніх вчителів математики, предметна і педагогічна підготовки вчителя математики, професійна спрямованість.

\section{Ярослав Владимирович Галета, \\ доиент кафедры педагогики и образовательного менеджмента, Кировоградский государственный педагогический университет имени В. Винниченко, ул. Шевченко, 1, г. Кропивницкий, Украина}

\section{ПРОБЛЕМЫ ПРОФЕССИОНАЛЬНОЙ ПОДГОТОВКИ УЧИТЕЛЯ МАТЕМАТИКИ В ПСИХОЛОГО-ПЕДАГОГИЧЕСКИХ ИССЛЕДОВАНИЯХ}

В статье рассмотрены исследования и публикации по проблеме профессиональной подготовки будущих учителей математики и подходы к решению соответствующих задач. Указано, что профессиональная подготовка является системным, многоплановым и многогранным явлением, имеющим определенное содержание и структуру. На основе научного исследования С. М. Рыбак определены противоречия методологического, дидактического и конструктивного характера в подготовке учителей физико-математического цикла. Освещена проблема формирования методической и информационной культуры учителя математики на основе концепции непрерывной методической подготовки учителя математики и осуществления межпредметных связей в процессе методической подготовки будущих учителей математики. Рассмотрен ряд противоречий, характеризующих 
уровень предметной и педагогической подготовки учителя математики, а именно: между содержанием учебнометодического обеспечения образования и объективной необходимостью наличия целостной дидактической системы преподавания дисциплины в педагогическом учреждении; между уровнем развития теоретических положений психологии и педагогики, практической значимости предметного содержания и унифицированностью, узкой направленностью методики преподавания учебной дисциплины в вузе; между ориентацией на построение содержания предметного образования на основе ее специфики и необходимости учета психологических характеристик сенсорно-перцептивных процессов адекватного восприятия математического содержания студентами. В результате анализа научной литературы выделены подходы к решению задач профессиональной подготовки будущего учителя математики: концепция подготовки специалиста, которая основывается на формировании профессиональной культуры (А. П. Томащук), концепция профессионально-педагогической направленности математической подготовки студентов (А. Г. Мордкович), система непрерывной методической подготовки, ориентированной на формирование математической культуры учителя математики (Н. Я. Виленкин).

Ключевые слова: проблемы профессиональной подготовки будущих учителей математики, предметная и педагогическая подготовки учителя математики, профессиональная направленность.

Рецензент: д. пед. н., проф. Т. Ю. Осипова

Подано до редакизії 07.12.2016

УДК: $378+376.68+81^{\prime} 233+008+659.1$

Аліна Анатоліївна Гадомська,
аспірант кафедри украйнської філології
іметодики навчання фахових дисииллін,
Південноукраӥнський наиіональний педагогічий університет імені К. Д. Ушинского,
вул. Старопортофранківська, 34, м. Одеса, Украйна
СТУДЕНТІВ ЗАСОБАМИ КРЕОЛІЗОВАНИХ РЕКЛАМНИХ ТЕКСТІВ: ВИДИ ВПРАВ

У статті розглядаються види вправ, які застосовуються під час лексичної роботи зі студентамиіноземиями задля формування $і$ збагачення їхнього словникового запасу засобами креолізованих рекламних текстів, наведено приклади використання конкретних текстів сучасної реклами як навчального матеріалу для формування лексичного запасу іноземних студентів.

Ключові слова: украӥнська мова як іноземна, іноземні студенти, лексичний запас, креолізовані рекламні тексти.

Актуальним для вищих навчальних закладів залишається створення умов для розвитку вторинної культурно-мовної особистості, яка володіє мовними засобами, має необхідні навички спілкування в усіх сферах україномовного середовища. Щорічно на навчання у виші України вступають інокомуніканти, які виросли в суспільствах, що за своїми звичаями, традиціями, законодавством, світоглядом, віросповіданням відрізняються від європейських. Потрапляючи в українське середовище, вони зустрічаються з проблемами не тільки соціальної адаптації, а й мовного характеру. Навчально-методичну роботу з формування мовленнєво-культурної адаптації в першу чергу слід спрямовувати на вдосконалення лексичних навичок студентів-іноземців.

Метою статті є окреслення системи вправ, які використовуються задля формування й збагачення лексичного запасу іноземних студентів.

У працях низки лінгводидактів (В. Костомаров, А. Фролкіна, А. Щукін) висвітлена проблема практи- чного засвоєння іншомовної лексики. Дослідження науковців щодо лексичної роботи зі студентамиіноземцями були присвячені лінгвістичним, психологічним та лінгводидактичним чинникам у збагаченні словникового запасу студентів-іноземців (3. Бакум, М. Баранов, С. Караман, Я. Коршунова), принципам укладання лексичного мінімуму з української мови як іноземної та презентації нової лексики для студентівіноземців (О. Туркевич) тощо.

Можна виділити наступні завдання, які постають перед викладачем в авдиторії інокомунікантів під час опанування лексичного мінімуму: формування активного й пасивного словникового запасу, забезпечення засвоєння студентами довкілля на чуттєвому й інтелектуальному рівнях для повноцінного оволодіння поняттями, зумовлюють вибір навчального матеріалу, який використовується для організації лексичної роботи. Оскільки найкраще для окреслених завдань слугують так звані прагматичні (автентичні) матеріали, запозичені з комунікативної практики носіїв мови 